\title{
Térdízületi MR vizsgálat ortopédiai diagnosztikai megbízhatósága
}

\author{
DR. SZUPER KINGA1 ${ }^{1}$ ROSTA BOGLÁRKA, DR. THAN PÉTER ${ }^{1}$, \\ DR. BOGNER PÉTER ${ }^{2}$, DR. HETÉNYI SZABOLCS ${ }^{3}$ DR. VERMES CSABA ${ }^{1}$
}

\section{ÖSSZEFOGLALÁS}

Napjaink ortopédiai gyakorlatában a térdízület diagnosztikájában az MR vizsgálat egyre szélesebb körben elérhető. A szerzők a PTE KK MSI Ortopédiai Klinikán 2010 és 2013 között 327 esetben végeztek térdízületi artroszkópiát, különböző eredetű térdpanaszok miatt, ebből 110 esetben előzetesen MR vizsgálat is történt. Prospektív vizsgálat során hasonlították össze az artroszkópia közben talált leletet az MR vizsgálat eredményével. Az esetek 68\%-ában találtak egyezést a két lelet között, 15\%-ban az MR által leírt elváltozást igazolni nem tudták, vagy egészen más laesio került felismerésre. A fennmaradó 17\%-ban az MR-en leírt elváltozásoknak csak egy részét sikerült artroszkópiával kimutatni. Megállapították, hogy az MR vizsgálat a medialis meniscus és a keresztszalag sérüléseinek diagnosztikájában a legpontosabb és csak kevésbé ad pontos információt a lateralis meniscus állapotáról. Az eredmények részletes bemutatása mellett a szerzők ismertetik a térdízületi MR vizsgálat indikációját, és áttekintik az ide vonatkozó irodalmi ajánlásokat.

\section{Kulcsszavak: $\quad$ Artroszkópia; Diagnosztika; MR vizsgálat; Meniscus sérülés; Térdsérülés;}

K. Szuper, B. Rosta, P. Than, P. Bogner, Sz. Hetényi, Cs. Vermes: Reliability of MR scanning in orthopaedic diagnostics

Nowadays, MR scanning is becoming more and more widely available for the diagnostics of the knee joint in our everyday orthopaedic routine. The authors performed 327 arthroscopies for knee disorders of diverse origin at the Orthopaedic Clinic of University Pécs in the period from 2010 to 2013; preliminary MR scanning was performed in 110 cases. Disorders detected with arthroscopy were compared to the findings of MR scanning in a prospective study. These two findings were identical in $68 \%$ of the cases; disorders described in the MR findings could not be verified in $15 \%$ of the cases or a completely different lesion was detected. Only a part of the disorders diagnosed with MR scanning could be verified with arthroscopy in the rest of the cases (17\%). The authors concluded that MR scanning is most reliable in the diagnostics of medial meniscus and cruciate ligament injuries and provides less accurate information about the lateral meniscus. In addition to detailed presentation of the results, authors review the indications of MR scanning and give an overview of the relevant guidelines in the literature.

Keywords: $\quad$ Arthroscopy-Methods; Knee injuries - Diagnosis; Magnetic Resonance Imaging - Methods; Menisci, tibial - Injuries; 


\section{BEVEZETÉS}

Az MR diagnosztika óriási hatással van a mozgásszervi képalkotásra és egyre gyakrabban használjuk a térdízület belső zavarainak vizsgálatában is.

Hazánkban sokszor hosszú várakozással járó, illetve költséges vizsgálat, klinikai előnye a fizikális vizsgálattal szemben még ma is vita tárgyát képezi. Számos szerző még mindig a fizikális vizsgálatot helyezi előtérbe és csak nem egyértelmú klinikai tünetek, vagy komplex térdsérülés estén javasol $M R$ vizsgálatot $(6,10,15)$.

$\mathrm{Az}$ egyik leggyakoribb, ugyanakkor legnehezebben megítélhető probléma a meniscus szakadás, amelynek gyanúja esetén az irodalmi közlemények négyféle vizsgáló módszert ajánlanak, ezek pedig a következők: fizikális vizsgálat, $M R$, ultrahang, diagnosztikus artroszkópia. A szerzők többsége egyetért abban, hogy a meniscus sérülések diagnosztikájában az $M R$ nem állhat a fizikális vizsgálat felett $(7,8,13)$. Szakorvos által elvégzett fizikális vizsgálat pontosabb a nem szakorvosénál, sőt még az MR leletnél is. Abban az estben, ha a vizsgálatot szakorvos végzi, annak rutinszerú MR-rel való kiegészítését is feleslegesnek tartják (7). Mások véleménye szerint, ha a fizikális vizsgálat megerősíti a meniscus szakadás gyanúját az MR eredménye már nem változtatja meg a kezelés módját (2), és az elvégzett artroszkópiák számát sem csökkenti (3). Természetesen a fentiekkel ellentétes véleményeket is publikáltak $(9,14)$.

A hagyományos térdízületi ultrahang lényegesen olcsóbb és szélesebb körben elérhető vizsgáló módszer, azonban a térdízületi diagnosztikában betöltött szerepe erősen vitatható, amelyet több tanulmány is vizsgált. Azzoni és munkatársai meniscus szakadás esetén a következőket figyelték meg: klinikai diagnózis alapján 321 betegnél végeztek térdultrahangot, ebből 216 esetben $M R$, illetve $C T$ vizsgálat is történt. Azt tapasztalták, hogy az esetek 44\%-ában volt az ultrahang diagnózis korrekt és 56\%-ában inkorrekt, ennek megfelelően alacsony volt a szenzitivitás $(60 \%)$, és specificitás $(21 \%)$ is (1). Maeseneer és munkatársai is hasonló megállapításra jutottak, ők 8 cadaver MR és ultrahang leletét hasonlították össze, és arra a következetésre jutottak, hogy az ultrahang a meniscus sérülés diagnosztikájában nem pontos (5). Ezzel szemben Riedl és munkatársai úgy találták, hogy az újabb, háromdimenziós ultrahang vizsgálat a meniscus szakadás kizárására hasznos lehet, azonban nem találtak különbséget a két- és háromdimenziós ultrahangos leletek pontossága között, viszont hangsúlyozták, logy mindẹn eseitben a vizsgálatot tapasztalt vizsgáló végezze (11).

Szalagsérülésekkel kapcsolatosan az irodalmi vélemények kevésbé megosztottak. Kostov és munkatársai az MR vizsgálat megbízhatóságát vizsgálták elülső keresztszalag sérülteknél, és azt találták, hogy a klinikai diagnózis 82,5\%-a egyezett az MR diagnózissal. Véleményük szerint az $M R$ vizsgálat pontos és nem invazív módszer a szalagsérülések megállapításában, és térd lágyrész sérülés esetén első vonalbeli vizsgálatként alkalmazható (8). Egy másik tanulmányban arra keresték a választ, hogy MR-rel elkülöníthető-e egymástól a stabil és instabil LCA szakadás, és arra a következtetésre jutottak, hogy az MR jelek nem teszik lehetővé a pontos megkülönböztetést. A tibia elülső transzlációja, a lateralis meniscus hátsó szarvának fedetlensége, az erősen feszülő hátsó keresztszalag instabil szakadást jelezhet (17). (Ebben a közleményben a szerzők a stabil, és instabil szakadás alatt a teljes, illetve a részleges LCA szakadást értették.)

A vizsgált lelet pontossága nagymértékben függ a vizsgáló tapasztalatától. Tekintettel arra, hogy véleményünk szerint napjaink gyakorlatában országos viszonylatban nem kizárólag specializált diagnoszták értékelik a felvételeket, vizsgálatunkban elsősorban arra voltunk kíváncsiak, hogy az általános MR leletezés milyen pontosságúnak tekinthető.

\section{ANYAG ÉS MÓDSZER}

Intézetünkben 2010 és 2013 között 327 esetben végeztünk térdízületi artroszkópiát különböző eredetű térdpanaszok miatt, ebből 110 esetben előzetesen MR vizsgálat is készült. A 110 beteg nemi megoszlása a következőt mutatta: 45 férfi és 65 nő. A betegek átlagéletkora 37 (21-53) év volt. 
Az MR felvételeket minden esetben a Pécsi Diagnosztikai Központban Siemens Magnetom 1,5 , illetve 3 Teslás MR-rel végeztük. $A z$ eredményeket kizárólag szenior radiológusok értékelték.

MR vizsgálatuk során az alábbi térdízületi elváltozások kerültek leírásra (természetesen egy MR vizsgálaton többféle patológia is szerepelhetett):

- meniscus szakadás, ezen belül 67 esetben medialis, 22 esetben lateralis meniscus szakadás; (1. ábra)

- szalagsérülés, ezen belül 45 esetben elülső keresztszalag szakadás, 5 esetben medialis collateralis szakadás, 7 esetben a lateralis collateralis szakadás,

- generalizált arthrosis 15 esetben,
- egyéb térdízületi patológia: 11 esetben chondromalatia patellae, 10 esetben Baker cysta, 11 esetben meniscus degeneráció, 2 esetben csont ödéma, 2 esetben ganglion a térd szalagrendszerén.

Ezt követően két portálból terápiás célú artroszkópiát végeztünk. A mútéteket 3 szenior operatőr végezte. Artroszkópia során ezeket az elváltozásokat találtuk: 52 medialis meniscus szakaciás, 12 lateraịs meniscus szakadás, 39 elülső keresztszalag szakadás, 1 osteochondritis dissecans, 1 medialis discoid meniscus, 1 villonodularis synovitis.

A mútétet követően összehasonlítottuk az MR és az artroszkópia során talált eredményeket, és csoportosítottuk a szerint, hogy volt-e leletegyezés, vagy sem.

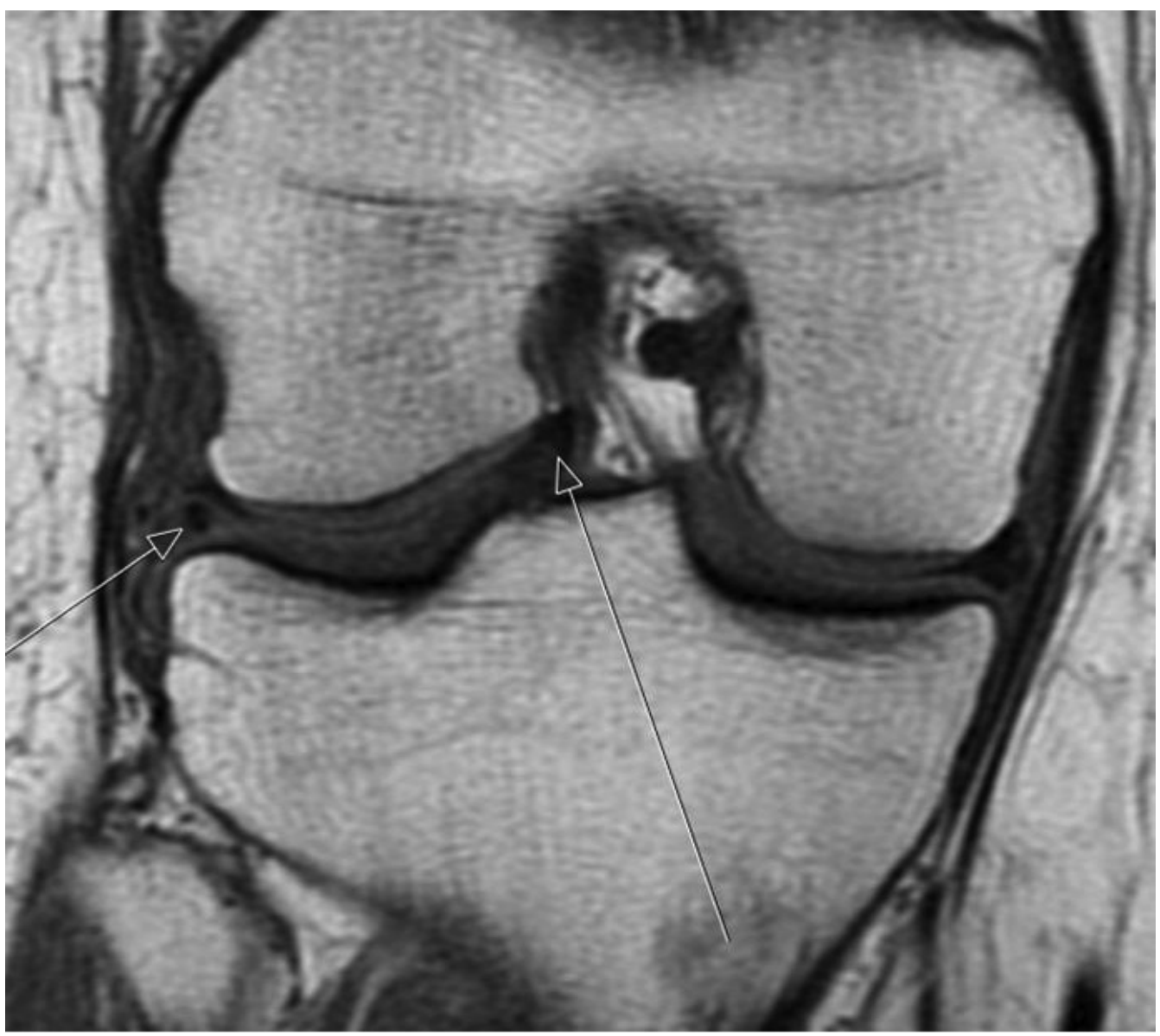

1. ábra T1 coronalis sík a lateralis meniscus kosárfül szakadása, fragmentum a fossa intercondylarisban. A medialis meniscus ép. 


\section{EREDMÉNYEK}

Vizsgálatunk során a következő eredményeket kaptuk. Az esetek 68\%-ánál találtunk egyezést az MR és artroszkópia során, 15\%-ban az MR által leírt elváltozást igazolni nem tudtuk, vagy egészen más laesio került felismerésre. A fennmaradó 17\%-ban az MR-en leírt elváltozásoknak csak egy részét sikerült artroszkópiával kimutatni.

$\mathrm{Az} M R$ és artroszkópia során talált elváltozások egyezését az I-II. táblázatok segítségével szemléltetjük. Táblázatainkból jól kiolvasható, hogy a leggyakoribb térdízületi sérülés a medialis meniscus szakadás, amit 52 esetben az MR, majd az azt követő artroszkópos vizsgálat is megerősített, és kisebb esetszámban (15 eset) találtunk csak pozitív MR lelet mellet negatív artroszkópos leletet, ugyanakkor 8 estet az MR vizsgálat nem írt le. A nagyszámú esetre való tekintettel megadhatjuk az MR vizsgálat medialis meniscus sérülésre vonatkozó szenzitivitását, valamint pozitív prediktív értékét, ami $86,66 \%$ és $77,61 \%$-nak adódott.

Elülső keresztszalag szakadás önmagában kisebb esetszámban fordult elő, és általában a medialis meniscus sérülésével társult. Ennél a sérülésformánál az MR vizsgálat szenzitivitása 81,25\%-nak, pozitív prediktív értéke $86,66 \%$ nak mutatkozott.

Lateralis meniscus szakadást lényegesen ritkábban írt le az MR vizsgálat, ami az elváltozás előfordulásának ritkaságát is jelentheti. Ebben az esetben az MR szenzitivitása, valamint pozitív prediktív értéke $70,58 \%$ és $54,54 \%$. Egyúttal 5 esetet nem véleményezett.

$\mathrm{Az}$ egyes diagnózis csoportokban a MR specificitását meghatározni nem tudjuk, hiszen vizsgálatunk egyik hiányossága, hogy nem volt egészséges kontrollcsoportunk, tehát olyan „betegek”, ahol teljesen negatív MR lelet ellenére elvégeztük volna az artroszkópiát.

\section{MEGBESZÉLÉS}

Vizsgálatunk a kis esetszám, valamint a kontrollcsoport hiánya miatt korlátozott értékű, azonban a kapott értékek biztosítják az összehasonlíthatóságot más tanulmányokkal, és felhívják a figyelmet arra, hogy a fizikális vizsgálat térdsérülések esetében nem hagyható figyelmen kívül, és semmiképpen sem előzheti meg az MR vizsgálat.

$\mathrm{Az}$ irodalomban a legtöbb tanulmány szerint az MR vizsgálat szenzitivitása, valamint pozitív prediktív értéke medialis meniscus sérülés esetén $65-95 \%$, és $83-99 \%$ között mozog, ami jól közelíti az általunk meghatározott süenzitivitás, és pozirív preuiliáv értékeket $(6,7,10,15-17)$.

LCA szakadás esetén a legtöbb tanulmány szerint az MR nagy pontosságú, amit a magas szenzitivitás és specificitás értékek szintén alátámasztanak. Kostov és munkatársai 103 beteget vizsgált LCA szakadás miatt, 60 valós pozitív, 25 valós negatív, 5 ál-pozitív, valamint 13 ál-negatív esetet talált, amely alapján $83 \%$-os szenzitivitást, és $88,37 \%$-os specificitást kapott (8). Rubin és munkatársainál a szenzitivitás 93\%-nak adódott. Számos hasonló prospektív tanulmány szerint a szenzitivitás 92-100\%, a specificitás 93-100\% között mozgott LCA szakadás esetén (13).

Vizsgálatunkban ezekhez az értékekhez képest csak kis eltérést kaptunk (szenzitivitás: 81,25\%), ami valószínúleg nem a vizsgálat pontatlanságából, hanem a kis esetszámból adódik, és ezért nem hasonlítható össze ezekkel a tanulmányokkal. Kis esetszám esetén is megfigyelhetjük azonban, hogy LCA sérült betegek között egyértelmúen negatív MR lelet mellett, csak 9 esetben találtunk definitív szakadást artroszkópia során, 39 betegünknél pedig megegyezett az artroszkópia és MR során talált diagnózis. Vizsgálatunkból látható, hogy az MR-rel nagy találati valószínűséggel állapíthatjuk meg a keresztszalagok szakadását.

Lateralis meniscus sérülés esetén eredményeink a nemzetközi irodalmi adatokkal összehasonlítva a kis esteszám ellenére is közelítőleg hasonló értékeket mutatnak. A legtöbb közleményben a szenzitivitás $61,5-73 \%$ a pozitív prediktív érték pedig $72,7-76 \%(6,10$, 15, 16).

Természetesen eredményeink kis esetszámra vonatkoznak, a későbbiekben tervezzük a vizsgálatot nagyobb betegpopuláción, valamint kontrollcsoporton is elvégezni. Mivel az MR vizsgálatokat nem minden esetben ugyanazzal a készülékkel végeztük, ezért felmerült, hogy érdemes 
lenne a 1,5 és 3T MR pontosságát különkülön is meghatározni az egyes diagnózis csoportokban.

Összefoglalva tehát az MR vizsgálat pontossága mind a meniscus sérülések, mind a szalagsérülések esetében ellentmondásos, azt azonban egyértelműen kijelenthetjük, hogy az ultrahang vizsgálatnak könnyű hozzáférhetősége ellenére kevésbé van létjogosultsága a térdsérülések diagnosztikájában.

Véleményünk szerint az MR vizsgálat elvégzésének nem egyértelmű fizikális tünetek, valamint komplex térdsérülés lehet az indikációja.

\section{I. táblázat Pozitiv MR lelet esetén talált artroszkópos eredmények}

\begin{tabular}{|c|c|c|}
\hline MR diagnózis & $\begin{array}{c}\text { Artroszkópiával igazolt esetek } \\
(\mathbf{d b})\end{array}$ & $\begin{array}{c}\text { Artroszkópiával nem igazolt esetek } \\
\text { (db) }\end{array}$ \\
\hline $\begin{array}{c}\text { Medialis meniscus } \\
\text { szakadás } \\
n=67\end{array}$ & 52 & 15 \\
\hline $\begin{array}{c}\text { Lateralis meniscus } \\
\text { szakadás } \\
n=22\end{array}$ & 12 & 10 \\
\hline $\begin{array}{c}\text { LCA szakadás } \\
n=45\end{array}$ & 39 & 6 \\
\hline $\begin{array}{c}\text { LCP szakadás } \\
n=2\end{array}$ & 0 & 2 \\
\hline
\end{tabular}

\section{II. táblázat Negativ MR lelet mellett talált intraarticularis elváltozások}

\begin{tabular}{c|c}
\hline MR-en nem leírt elváltozások & $\begin{array}{c}\text { Artroszkópiával igazolt esetek } \\
\text { (db) }\end{array}$ \\
\hline Medialis meniscus szakadás & 8 \\
\hline Lateralis meniscus szakadás & 5 \\
\hline LCA szakadás & 9 \\
\hline
\end{tabular}




\section{IRODALOM}

1. Azzoni R., Cabitza P.: Is there a role for sonography in the diagnosis of tears of the knee menisci? J. Clin. Ultrasound, 2002. 30: 472-476.

2. Boden S. D., Labropoulos P. A., Vaislas J. C.: MR scanning of the acutely injured knee: sensitive, but is it cost effective? Arthroscopy, 1990. 4: 306-310.

3. Bridgman S., Richards P. J., Walley G., MacKenzie G., Clement D., Mc Call I., Griffiths D., Maffuli N.: The effect of magnetic resonance imaging scans on knee arthroscopy: randomized controlled trial. Arthroscopy, 2007. 23: 1167-1173.

4. Brooks S., Morgan M.: Accuracy of clinical diagnosis in knee arthroscopy. Ann. R. Coll. Surg. Engl. 2002. 84: 265-268.

5. De Maseneer M., Lenchick L., Starok M.: Normal and abnormal medial meniscocapsular structure: MR imaging and sonography in cadavers. Am. J. Roentgenol. 1998. 171. (4): 969-976.

6. Dutka J., Skowronek M., Dutka L.: Arthroscopic verification of the orthopaedic examınationi and miayneiti iesoriarice imaging in intra-articular knee injury. Retrospective study. Wideochir Inne Tech Maloinwazyjne. 2012. 7. (1): 13-18.

7. Ercin E., Kaya I., Sungur I., Demirbas E., Ugras A. A., Cetinus M. E.: History, clinical findings, magnetic resonance imaging, and arthroscopic correlation in meniscal lesions. Knee Surg. Sports. Traumatol. Arthrosc. 2012. 20: 851-856.

8. Kostov H., Stojmenski S., Kostova E.: Reliability assessment of arthroscopic findings versus MRI in ACL injuries of the knee Acta Inform. Med. 2014. 22: 111-114.

9. Lokannavar S. H., Yang X., Guduru H.: Arthroscopic and low- field MRI (0,25T). Evaluation of meniscus and ligaments of painful knee. J. Clin. Imag. Sci. 2012. 2: 1-4.

10. Navali M., Bazavar M., Mohseni A., M., Safari B., Tabrizi A.: Arthroscopic evaluation of the accuracy of clinical examination versus MRI in diagnosing meniscus tears and cruciate ligament ruptures. Arch. Iran. Med. 2013. 16. (4): $229-232$.

11. Riedl S., Tauscher A., Kuhner C.: Three dimensional ultrasound in the clinical diagnosis of meniscus lesions in German. Ultraschall Med. 1998. 19-28.

12. Rose N. E., Gold S. M.: A comparision of accuracy between clinical examination and magnetic resonance imaging in the diagnosis of meniscal and anterior cruciate ligament tears. Arthroscopy 1996. 12: 398-405.

13. Rubin D.A., Kettering J.M., Towers J.D., Britton C.A.: MR imaging of the knee having isolated and combined ligament injuries. Am. J. Roentgenol. 1998. 170: 1207-1213.

14. Ruwe P. A., Wright J., Randall R. L., Lynch J. K., Jokl P., McCarthy S.: Can MR imaging effectively replace diagnostic arthroscopy? Radiology, 1992. 183: 335-339.

15. Siddiqui M., Ahmad I., Sabir A., Ullah E., Rizivi A.A.S., Rizivi A.W.S.: Clinical examination vs.MRI: Evaluation of diagnostic accuracy in detecting ACL and meniscal injuries in comparison to arthroscopy. Pol. Orthop. Traumatol. 2013. 78: 59-63.

16. Subhas N., Sakamoto A. F., Mariscalo W. M., Polster M. J., Obuchowski A. N., Jones H. M.: Accuracy of MRI in the diagnosis of meniscal tears in older patients Am. J. Roentgenol. 2012. 198: 575-580.

17. Van Dyck P., Gielen L., J., Vanhoenacker M., F., Wouters K., Dossche L., Parizel M., P.: Stable or unstable tear of the anterior cruciate ligament of the knee: an MR diagnosis? Skelet. Radiol. 2012. 41: 273-280.

18. Yilgor C., Atay A. O., Ergen B., Doral N. M.: Comparision of magnetic resonance imaging findings with arthroscopic findings in discoid meniscus Knee Surg. Sports Traumatol. Arthrosc. 2014. 22: 268-273.

\section{Dr. Szuper Kinga}

PTE KK MSI Ortopédiai Klinika

7632 Pécs, Akác u. 1. 